\title{
Eastern Cottontail Use of Fragmented Farmland Habitat ${ }^{1}$
}

\author{
Robert K. SWIHART ${ }^{2}$ \& Richard H. YAHNER ${ }^{3}$
}

Swihart R. K. \& Yahner R. H., 1982: Eastern cottontail use of fragmented farmland habitat. Acta theriol., 27, 19. 257-273 [With 5 Tables \& 2 Figs.]

Biotic and abiotic features influencing summer-fall habitat use by the eastern cottontail, Sylvilagus floridanus (Allen, 1894), were investigated in an intensively-farmed region of southern Minnesota, USA, during 1979 and 1980. Differential suitability of shelterbelt, waste area, and fencerow/roadside habitat types also was examined. Stepwise discriminant analysis revealed that cottontail use of trap stations was associated with dense woody vegetation and artificial cover. Individuals occurring in shelterbelts were in better physical condition than individuals in waste areas or fencerows/roadsides, and populations in shelterbelts declined less than those in the other 2 habitat types. Shelterbelts also were suited better to permanent occupancy and supported higher cottontail densities than waste areas or fencerows/roadsides. Females, juveniles, and adults were indiscriminant in their use of habitat types, whereas males were captured in a greater proportion of shelterbelt and waste area traps than expected. Harvest of field crops coincided with increased use of shelterbelts and waste areas.

[Dept. of Entomol., Fisheries and Wildl., Univ. Minnesota, St. Paul, Minnesota 55108 USA]

\section{INTRODUCTION}

Intensive farming practices during the past 20 years have reduced drastically the quantity and the quality of habitat types suitable for wildlife species (Labisky, 1976 ; Vance, 1976). In addition, intensive cashgrain farming has resulted in patches of habitat that are isolated by extensive areas of field-crop monocultures (Gottfried, 1979; Wegner \& Merriam, 1979). This habitat fragmentation exerts a strong influence on behavioral and physiological states of individuals (Wiens, 1976) and increases the likelihood of local extinction of populations inhabiting these patches (Simberloff, 1974).

The eastern cottontail, Sylvilagus floridanus, is common to agricultural areas in the midwestern United States (Evans \& Probasco, 1977). This

${ }^{1}$ Paper No. 11818. Minnesota Agricultural Experiment Station, Scientific Journal Series, University of Minnesota, St. Paul, MN 55108.

2 Present address: Dept. of Ecology and Systematics and Museum of Natural History, Univ. Kansas, Lawrence, KS 66045 USA.

${ }^{3}$ Present address: Forest Resources Laboratory, School of Forest Resources, The Pennsylvania State Univ,, University Park, PA 16802 USA. 
species typically is regarded as a habitat generalist; Lord (1963) concluded that cottontails thrive on mosaic patterns of divergent habitat types. Previous studies have reported $S$. floridanus use of woodlots (Trent \& Rongstad, 1974), fencerows (Linder \& Hendrickson, 1956), roadsides (Kline, 1965 ; Bigham, 1970), cultivated fields (Friley, 1955 ; Trent \& Rongstad, 1974), windbreaks and shelterbelts (Hendrickson, 1947; Podoll, 1979), waste areas (Allen, 1949; Friley, 1955), and hedgerows (Kabat \& Thompson, 1963). Although the investigations above depict general habitat use and preferences, they lack quantification and/or fail to reflect the impact on $S$. floridanus of extreme habitat fragmentation caused by modern agricultural practices. Further, because of sharp declines in the central United States' cottontail population (Schwartz, 1973), a quantitative examination of $S$. floridanus habitat use in an intensively-farmed area is necessary. Consequently, primary objectives of the present study were to identify differential use of habitat types and to quantify biotic and abiotic features influencing habitat use by cottontails. Determination of features associated with cottontail use of fragmented habitat will assist landowners interested in maintaining healthy, viable populations.

\section{STUDY AREA}

The study was conducted on the University of Minnesota's Rosemount Agricultural Experiment Station, Dakota County, Minnesota, USA, from July to November 1979 and 1980. Land-use practices and habitat types at Rosemount were characteristic of intensively-farmed areas in southern Minnesota. Hunting is not permitted at the Station.

Three habitat types were investigated: shelterbelts, waste areas, and fencerows! roadsides. These 3 habitat types are commonly-occurring, permanent vegetative areas available to cottontails in many agricultural regions of the central United States. Shelterbelts are multi-row plantings of trees and shrubs providing protection for farm buildings and livestock by reducing wind velocity and snow drifting when positioned in northerly and westerly directions (Smith and Scholten, 1980). In the present study, waste areas are defined as idle land not used for pasture or cultivation due to soil characteristics and/or topography; such areas are useless only with respect to agricultural production. Fencerows/roadsides are designated as strips of vegetation either adjoining fenced borders of fields or parallel and adjacent to secondary roads.

Five shelterbelts (S1-S5), 3 waste areas (W1-W3), and 5 fencerows/roadsides (F1-F5) were selected as study sites (Fig. 1). These 13 sites were chosen because their plant species composition, size, and proximity to cultivated fields and other human activity correspond with those typically encountered throughout the region. Shelterbelts consisted principally of woody species, including Pinus resinosa, P. banksiana, P. ponderosa, Picea glauca, P. pungens, Populus deltoides, Ulmus americana, Rubus occidentalis, Caragana arborescens, Acer saccharinum, A. negundo, 
Fraxinus pennsylvanica, and Lonicera tatarica. Dominant herbaceous vegetation included Poa pratensis, Plantago, and Solidago. Sizes of shelterbelts were 0.70 , $0.79,0.37,1.01$, and 0.90 ha for S1, S2, S3, S4, and S5, respectively. Approximate dates of establishment for S1-S5 were 1946, 1961, 1949, 1951, and 1930, respectively. S1 and S4 each contained 4 rows of trees, whereas S2, S3, and S5 consisted of 9,8 , and 5 rows, respectively. A further description of S1, S2, S3, and S4 is given by Yahner (1980). Waste areas contained scattered deciduous shrubs and small ( $<5 \mathrm{~m}$ tall) trees, primarily Ulmus pumila; common herbaceous species included Bromus, Sporobolus cryptandrus, Agropyron repens, Setaria viridis, Antennaria, Silene cucubalus, and Melilotus. Areal extent of waste areas and fencerows/road-

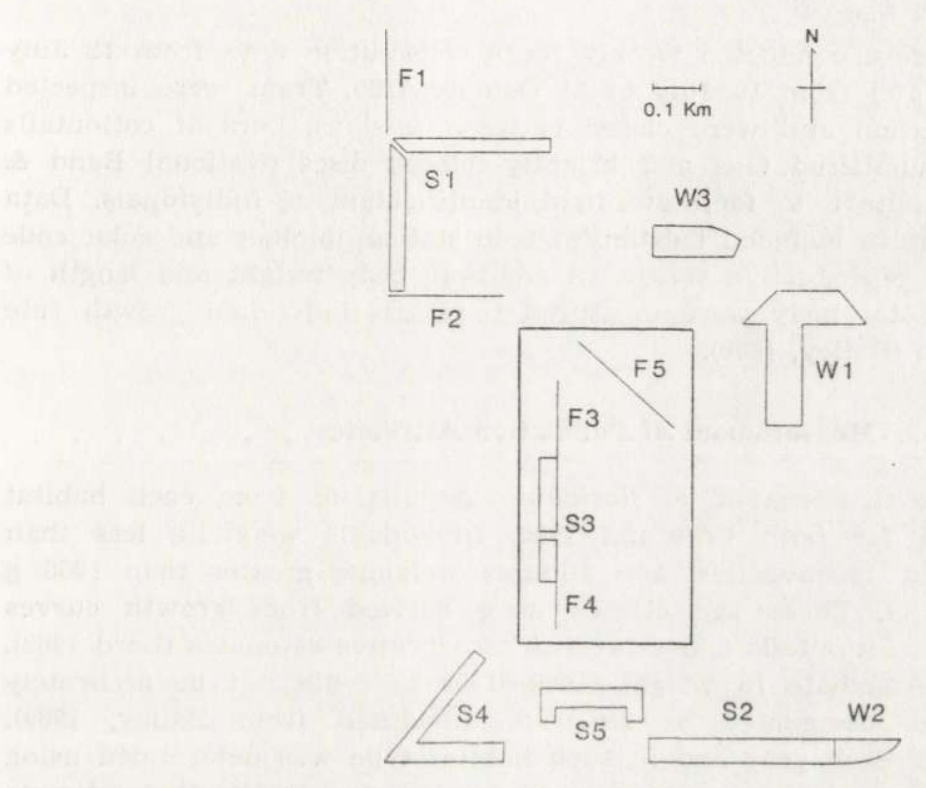

Fig. 1. Orientation and configuration of study sites at the Rosemount Agricultural Experiment Station, Dakota County, Minnesota, USA. Study sites contained within the inset (S3, F3, F4, F5) are located approximately $3 \mathrm{~km}$ and $160^{\circ}$ from W2. $\mathrm{S}=$ shelterbelt; $\mathrm{W}=$ waste area $\mathrm{F}=$ fencerow $/$ roadside.

sides influenced by traps was calculated using a $30-\mathrm{m}$ strip centered on trap stations and positioned perpendicular to the transect line used to establish locations of trap stations (see below). This arbitrary but convenient width coincided with the maximum width of the 5 shelterbelts studied and equalled the diameter of the largest sampling unit used in quantifying vegetative characteristics of trap stations (see below). Effective areas for W1, W2, and W3, then, were 1.14, 0.42, and 0.57 ha. All waste area study sites were established in 1942. Fencerows/roadsides consisted almost entirely of herbaceous vegetation, including Bromus, Melilotus, Trifolium, Medicago sativa, Abutilon theophrasti, Asclepias syriaca, Plantago, and Solidago. F1, F2, and F5 were each 0.72 ha, whereas F3 and F4 were 0.42 and 0.27 ha, respectively. 


\section{METHODS}

\section{Field Techniques}

Collapsible live traps (Tomahawk Live Trap Co., $23 \times 23 \times 66 \mathrm{~cm}$ ) were placed at $50-\mathrm{m}$ intervals along medial transects positioned parallel to the major axis of each study site; position of the initial trap in a transect was selected randomly. Numbers of traps per habitat type were 40,15 , and 20 in shelterbelt, waste area, and fencerow/roadside, respectively. Traps were wrapped with heavy-duty roofing paper and bound with wire to minimize stress induced by capture, predators, and exposure (Fitzsimmons, 1978).

Trapping sessions were conducted weekly for 4 consecutive days from 12 July to 9 November 1979 and from 16 July to 31 October 1980. Traps were inspected daily during each session and were closed between sessions. Ears of cottontails were marked with numbered tags and brightly-colored discs (National Band \& Tag Co.) at initial capture to facilitate field identification of individuals. Data recorded for each capture included location of trap station, number and color code of ear tags, sex, and reproductive status. In addition, body weight and length of hind foot, ear, and total body were measured to assess individual growth rate and physical condition (Bailey, 1968).

\section{Measurement of Population Attributes}

Age- and sex-class structure of $S$. floridanus populations from each habitat type were calculated for both 1979 and 1980. Individuals weighing less than $1050 \mathrm{~g}$ were classified as juveniles, and animals weighing greater than $1300 \mathrm{~g}$ were considered adults. These age classes were derived from growth curves established for Illinois cottontails and represent conservative estimates (Lord 1963). Ages of animals intermediate in weight $(1050-1300 \mathrm{~g})$ could not be accurately determined and were designated as "unaged" (modified from Bailey, 1969). Population density for each year and in each habitat type was determined using a conservative, nonparametric estimate derived by Overton (1971); this estimate is useful for populations containing individuals with low and/or unequal capture probabilities (Overton, 1971; Zarnoch, 1979).

Physical condition of individuals was assessed using a condition index (CI) derived from a regression of body weight on total length (Bailey, 1968). This index enables comparisons of samples with differing age structures and may be expressed as $C I=W / L^{3}$, where $W$ represents weight $(\mathrm{g})$ and $L$ is total length (dm) (Chapman et al., 1977). Cottontails typically experience weight losses following capture, and these losses may persist for 10 days (Bailey, 1968); consequently CI values for individuals recaptured before expiration of this 10 -day period were excluded from analyses. CI values were compared among the 3 habitat types using either single-classification analyses of variance (Sokal \& Rohlf, 1969) or KruskalWallis tests (Conover, 1971).

\section{Habitat Quantification}

Biotic and abiotic habitat features around each trap station were measured in July and August 1980. Three sampling units were centered on each trap, including a $1.0-\mathrm{m}^{2}$ circle, 2 perpendicular $30-\mathrm{m}^{2}$ arm-length transects, and a $15-\mathrm{m}$ radius 
circular plot (modified from Dueser \& Shugart, 1978). Proximity and areal extent of land-use practices within a $71-\mathrm{m}$ radius (1.6 ha) of each station were estimated from on-site observations and digitized aerial photographs. The 1.6 ha circle was chosen because it approximates summer-fall home ranges sizes of S. floridanus reported in the literature (e.g., Trent \& Rongstad, 1974). The sampling process yielded measures of 33 variables characterizing vegtative and physical habitat features surrounding each trap station. Of these original 33 variables, 10 were selected for use in statistical analyses (Table 1) based on 3 criteria: 1) each variable must possess a clear ecological interpretation; 2) correlations between variables should be minimized $(r<0.75)$ to reduce the likelihood of redundancy in the data set; and 3) each variable should yield a significant univariate F-value $(P<0.05)$ for overall differences between successful and unsucessful trap stations (cf. Dueser \& Shugart, 1979).

Table 1

Description of biotic and abiotic features and associated sampling procedures employed to assess habitat use by cottontail rabbits at the Rosemount Agricultural Experiment Station, Dakota County, Minnesota, USA (several variables modified from Dueser and Shugart, 1978).

Acronym

Definition and Sampling Method

ARTAREA Mean area per artificial cover site (e.g., abandoned sheds, junkpiles) with a trap-centered $15-\mathrm{m}$ radius

CONIFER ${ }^{1} \quad$ Percentage of coniferous overstory vegetation calculated from 20 ocular tube sightings read to the nearest $10 \%$ along the center lines of two perpendicular $30-\mathrm{m}^{2}$ trap-centered transects

CULTAREA Percentage of a $71-\mathrm{m}(1.6 \mathrm{ha})$ trap-centered circle subjected to cultivation as calculated from digitized aerial photographs

GRASS Percentage of grassy vegetation (Graminae); see CONIFER for sampling method

GRASS $>2$ Percentage of a $71-\mathrm{m}$ (1.6 ha) trap-centered circle subjected to mowing at frequencies exceeding 2 per growing season; values were estimated from on-site observations and digitized aerial photographs

SHRUBCOV 2 Percentage of shrubby vegetation; see CONIFER for sampling method

SHRUBDIS 2 Distance $(\mathrm{m})$ from trap to nearest shrubby vegetation occurring at a density of $>10$ stems per $\mathrm{m}^{2}$

STUMPDEN Number of tree stumps $\geqslant 7.5 \mathrm{~cm}$ in diameter within a trapSTUMPDIS

WOODVEG Number of shoulder-high contacts with live woody vegetation as derived from two perpendicular $30-\mathrm{m}^{2}$ trap-centered transects

1 Ovestory vegetation is defined as live woody vegetation $\geqslant 7.5 \mathrm{~cm} d b h$.

2 Shrubby vegetation is defined as live woody vegetation $\leq 1.0 \mathrm{~m}$ in height.

\section{Analysis of Habitat Use}

Differences in the relative proportion of traps used among the 3 habitat types were evaluated using contingency tables cross-classified by habitat type and number 
of successful and unsuccessful traps. Analyses were conducted for each age class (juvenile, unaged, and adult), sex class, year, and before and after harvest of field crops proximal to trap stations.

A residency index was calculated for each habitat type to determine the relative proportion of resident individuals per unit area of habitat. A resident in this study was defined as an individual occupying a given study site for at least 2 consecutive weeks, based on capture records and observations. We express this index as

$$
R I=\log _{e}\left(X_{i} / Y_{i}\right),
$$

where $X_{i}$ represent the proportion of all resident individuals occupying habitat type $i$, and $Y_{i}$ represents the proportional of total area that is comprised of habitat type $i$. An $R I$ value of 0 indicates that the proportion of resident individuals in the $i$ th habitat type equals the proportion of total habitat comprised of type $i$. A positive $R I$ value suggests that more individuals than expected are residents of habitat type $i$, based on the relative availability of habitat type $i$; the converse is true for negative $R I$ values.

Successful and unsuccessful trapping stations were analyzed by stepwise discriminant analysis (BMDP7M; Dixon \& Brown, 1979) for each age class, sex class, year, and before and after crop harvest, resulting in 19 analyses of 2 groups (successful and unsuccessful stations). Square root transformations were used to stabilize variances (Chatterjee \& Price, 1977) for each 2-group, 10-variable (Table 1) data set prior to analysis. An $F$-value of 4.0 was used for determining variable entry and removal in the stepping process. Rao's $F$ (Rao, 1973) was computed to test for discriminating ability of the discriminant functions; in addition, canonical values of group means, canonical coefficients of the selected habitat variables, and $F$-to-enter values for these habitat variables were calculated.

Based on the 10 habitat features per trap location (Table 1), stepwise discriminant analysis again was used to test for segregation in habitat use among age classes, between sex classes and years, and before and after harvest. Only trap stations capturing cottontails were considered in these analyses.

\section{RESULTS}

\section{Population Attributes}

A total of 7834 trap nights resulted in 114 captures of 71 individuals. Recapture rates did not differ between juveniles and adults $(P>0.10)$. The overall sex ratio of 1.09 males : 1.00 females was not significantly different from a balanced ratio $(P>0.20)$. Age structure was also similar between years $(P>0.20)$, with juveniles comprising $75.9 \%$ of the knownage population. Capture rate per trap night was $2.32 \%$ in 1979 and $0.86 \%$ in 1980. Population densities estimated from July through October for all study sites combined declined from 7.8 individuals/ha in 1979 to 3.5 individuals/ha in 1980 . Food availability presumably was not a determinant in differential trap success among habitat types, because 
the proportion of bait eaten $(<50 \%$ or $>50 \%$ ) was similar among habitat types $(P>0.10)$ and did not change in response to crop harvest $(P>0.50)$. Likewise, wrapping traps with roofing paper did not appear to alter trap responses of $S$. floridanus (Swihart, 1981).

Mean $C I$ values for adult $(\bar{x}=5.82)$, unaged $(\bar{x}=5.60)$, and juvenile $(\bar{x}=5.78)$ segments of the Rosemount population exhibited no differences $(P>0.10)$, but females $(\bar{x}=5.84)$ displayed significantly higher mean values than males $(\bar{x}=5.59 ; P<0.05)$. Mean $C I$ values were similar between $1979(\bar{x}=5.71)$ and $1980(\bar{x}=5.77 ; P>0.20)$, and no significant correlation existed between date of capture and physical condition $(r=-0.08, P>0.20)$.

\section{Use of Habitat Types}

Arbitrary classification of habitat types as shelterbelts, waste areas, and fencerows/roadsides is meaningless unless these classifications reflect actual differences in habitat features. Consequently, validity of this habitat categorization was tested using stepwise discriminant analysis. Trap stations were grouped according to habitat type, and discriminatory ability of the transformed habitat variables measured at each station (Table 1) was examined. STUMPDIS, WOODVEG, CULTAREA, SHRUB-

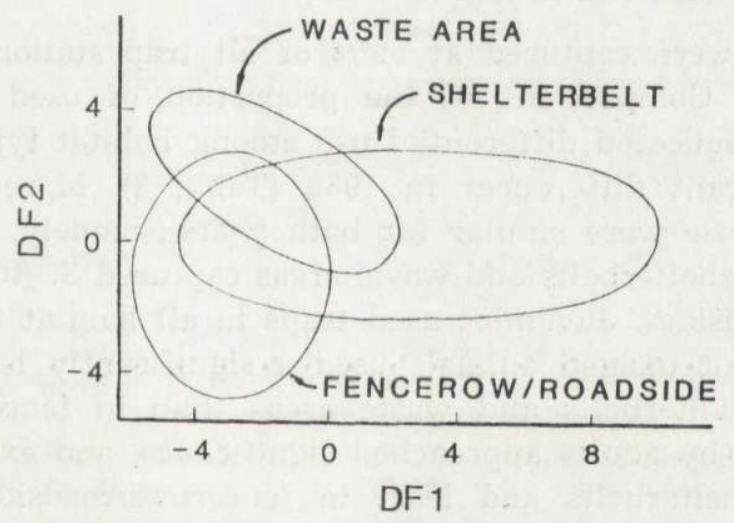

Fig. 2. Ninety-five percent confidence ellipses for trap stations grouped according to habitat type and plotted in discriminant space. Confidence regions were computed using the principal axes technique of Sokal \& Rohlf (1969).

$D I S$, and CONIFER each contributed significantly $(P<0.05)$ to the power of the discriminant functions (Rao's $F=37.90, \mathrm{df}=10.136 ; P<0.01$ ). DF1 discriminates between traps occurring in shelterbelts versus those occurring in waste areas or fencerows/roadsides (Fig. 2). All shelterbelts in this study contained conifers and relatively dense concentrations of i-Acta Theriologica 
shoulder-high woody vegetation and stumps (Table 2); in addition, shelterbelts, because of their proximity to farmsteads, were more isolated from cultivated land than waste areas or fencerows/roadsides (Table 2). DF2 segregates waste area and fencerow/roadside trap stations based on isolation from cultivated land and proximity to shrubs and stumps (Table 2, Fig. 2). The paucity of overstory vegetation in waste areas as well as the proximity of fencerows/roadsides to wooded sites (e.g., shelterbelts) explains the lower mean value of STUMPDIS for waste areas versus fencerows/roadsides (Table 2).

Table 2

Mean $(\bar{x}) \pm$ standard error (SE) for untransformed habitat variables used to classify trap stations in shelterbelts $(N=40)$, waste areas $(N=15)$, and fencerows/roadsides $(N=20)$ via stepwise discriminant analysis.

\begin{tabular}{lrrrrrr}
\hline \multirow{2}{*}{ Variable } & \multicolumn{2}{c}{ Shelterbelt } & \multicolumn{2}{c}{ Waste Area } & \multicolumn{2}{c}{ Fencerow/Roadside } \\
& $\bar{x}$ & SE & \multicolumn{1}{c}{$\bar{x}$} & SE & & \multicolumn{1}{c}{ SE } \\
\hline & & & & & & \\
STUMPDIS & 20.6 & 3.6 & 308.3 & 34.2 & 79.8 & 17.8 \\
WOODVEG & 22.5 & 1.6 & 4.5 & 2.5 & 0.7 & 0.4 \\
CULTAREA & 26.1 & 2.1 & 38.2 & 2.4 & 73.9 & 3.2 \\
SHRUBDIS & 3.8 & 0.8 & 12.8 & 3.3 & 82.2 & 17.3 \\
CONIFER & 15.4 & 2.5 & 0.0 & 0.0 & 0.0 & 0.0 \\
\hline
\end{tabular}

1 Variables are arranged in order of entry into the discriminant functions; see Table 1 for an explanation of variable acronyms.

Cottontails were captured at $59 \%$ of all trap stations and in all 3 habitat types. Comparisons of the proportion of used versus unused trap stations indicated differential use among habitat types in 1979 and nearly significant differences in 1980 (Table 3). Moreover, trends in $S$. floridanus use were similar for both years ; namely, proportionately more traps in shelterbelts and waste areas captured $S$. floridanus than in fencerows/roadsides. Juveniles used traps in all habitat types in similar proportions, but unaged animals used a significantly larger proportion of traps in shelterbelts and waste areas than in fencerows/roadsides. Divergent use by adults approached significance, and extent of use was greatest in shelterbelts and least in fencerows/roadsides. Males used a higher proportion of traps in both shelterbelts and waste areas than in fencerows/roadsides, whereas females used similar proportions of traps in all 3 habitat types (Table 3).

Population densities (individuals/ha) for 1979 versus 1980 dropped from 10.1 to 1.8 in waste areas ( $82 \%$ decrease), from 3.7 to 1.1 in fencerows/roadsides ( $70 \%$ decrease), and from 11.5 to 9.0 in shelterbelts ( $22 \%$ decrease). Hence, all habitat types exhibited population declines, but severest losses apparently were incurred in waste areas and fencerows/roadsides. 
Mean $C I$ values differed among the 3 habitat types $(\mathrm{P}<0.05)$, but a posteriori pairwise comparison failed to identify the nature of this difference. Although not significant, $95 \%$ confidence intervals for paired comparisons indicated the following order of mean $C I$ values: shelterbelt $>$ fencerow/roadside $>$ waste area. $R I$ values were $0.48,0.03$, and -1.87 for shelterbelts, waste areas, and fencerows/roadsides, respectively.

Table 3

Pearson's $\chi^{2}$ test for homogeneous proportions of habitat type $\times$ trap success/failure for each year, age class, sex class, and before and after harvest.

\begin{tabular}{|c|c|c|c|}
\hline $\begin{array}{c}\text { Classification } \\
\text { Criteria }\end{array}$ & $\chi^{2}$ & $\begin{array}{c}\text { Paired } \\
\text { Comparison } \\
\end{array}$ & $\begin{array}{c}\text { Approximate } \\
\chi^{2} \\
\end{array}$ \\
\hline 1979 & $9.39^{* *}$ & $\begin{array}{l}S-F \\
W-F \\
S-W\end{array}$ & $\begin{array}{l}7.30^{* *} \\
5.87^{* *} \\
0.00 \mathrm{NS}^{1}\end{array}$ \\
\hline $\begin{array}{l}1980 \\
\text { Juvenile }\end{array}$ & $\begin{array}{l}4.69^{* *} \\
4.45 \mathrm{NS}^{1}\end{array}$ & & \\
\hline Unaged & $10.72^{* *}$ & $\begin{array}{l}S-F \\
W-F \\
S-W\end{array}$ & $\begin{array}{c}8.04^{* *} \\
10.48^{* *} \\
0.79 \text { NS }\end{array}$ \\
\hline $\begin{array}{l}\text { Adult } \\
\text { Female }\end{array}$ & $\begin{array}{l}5.03^{*} \\
3.21 \text { NS }\end{array}$ & & \\
\hline Male & $16.87^{* *}$ & $\begin{array}{l}S-F \\
W-F \\
S-W\end{array}$ & $\begin{array}{l}15.31^{* *} \\
12.70^{* *} \\
0.03 \mathrm{NS}\end{array}$ \\
\hline $\begin{array}{l}\text { Pre-harvest } \\
\text { Post-harvest }\end{array}$ & $\begin{array}{l}1.87 \mathrm{NS} \\
10.86^{* *}\end{array}$ & $\begin{array}{l}S-F \\
W-F \\
S-W\end{array}$ & $\begin{array}{c}10.80^{* *} \\
4.23^{* *} \\
0.63 \text { NS }\end{array}$ \\
\hline
\end{tabular}

${ }^{1} \mathrm{NS}=P>0.10, * 0.05<P<0.10,{ }^{* *} P<0.05 ; \mathrm{df}=2$.

$2 \mathrm{~S}=$ Shelterbelt, $\mathrm{W}=$ waste area, $\mathrm{F}=$ Fencerow/roadside.

To determine the impact of crop harvesting on $S$. floridanus use of habitat types, the proportion of used and unused trap stations in each habitat type was compared for differences before and after harvest of adjacent field crops. No difference in relative use of habitat types existed prior to harvest, but a greater proportion of shelterbelt and waste area traps captured cottontails after harvest compared to traps in fencerows/roadsides (Table 3). Furthermore, mean post-harvest probability of capture increased significantly from pre-harvest levels for shelterbelts $(0.56 \%$ to $2.99 \%, P<0.001)$ and waste ares $(0.38 \%$ to $2.13 \%$, $P<0.005)$, but not for fencerows/roadsides $(0.42 \%$ to $0.83 \%, P>0.75)$. No shifts in age-class structure or sex ratio occurred in any habitat type as a result of crop harvest ( $P>0.10$ in all instances). 


\section{Features Influenoing Habitat Use}

In 9 separate analyses, stepwise discrimination identified habitat variables significantly influencing $S$. floridanus habitat use (Table 4). WOODVEG segregated use and unused trap stations for females, whereas

\section{Table 4}

Stepwise discriminant analysis performed on 2 groups (successful and unsucessful trap stations) using transformed habitat variables measured at each trap station. A separate analysis was performed for each year, age class, sex class, and before and after harvest.

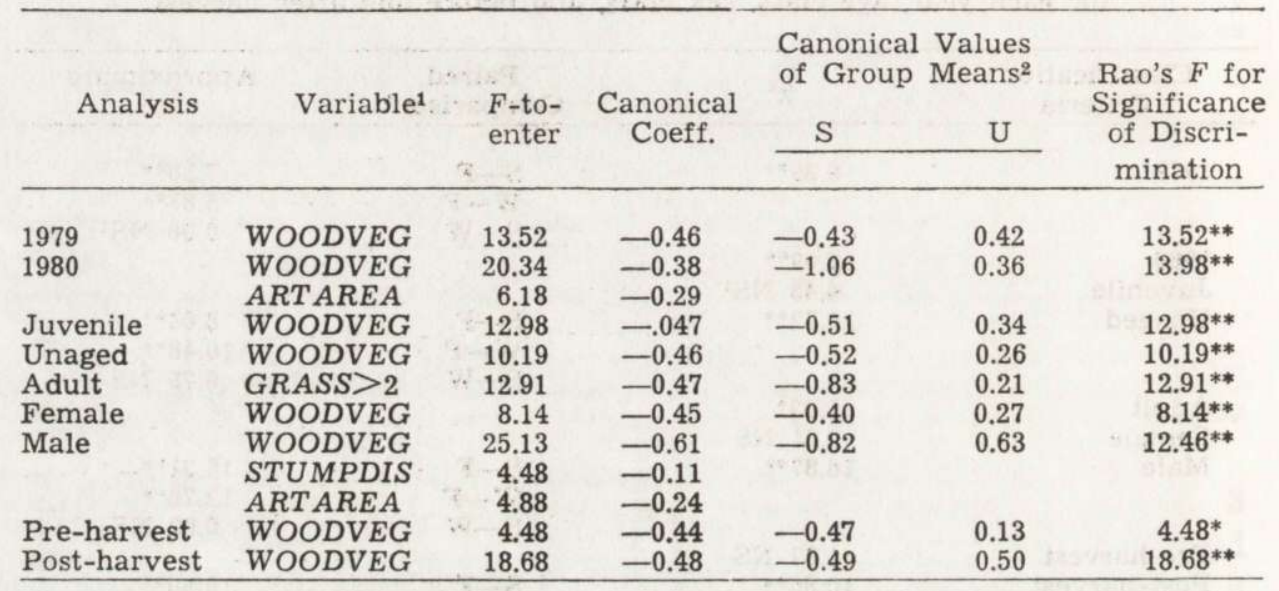

1 Variables are arranged in order of entry into the discriminant function; see Table 1 for an explanation of acronyms. ${ }^{2} \mathrm{~S}=$ Successful traps; $\mathrm{U}=$ Unsuccessful traps. ${ }^{*} P<0.05,{ }^{* *} P<0.01$

WOODVEG, STUMPDIS, and ARTAREA combined to explain trap station use by males. Juvenile trap use was significantly influenced by WOODVEG ; also, ART AREA was nearly significant in contributing to separation of trap stations $(0.05<P<0.10)$. WOODVEG affected trap use by unaged individuals, but differential use of trap stations by adults was explained using GRASS $>2$. Mean values of WOODVEG differed significantly between groups in 1979, and WOODVEG and ARTAREA were responsible for group separation in 1980. Finally, both pre-harvest and post-harvest trap station use were significantly influenced by WOODVEG. In all 9 analyses, mean values were larger for the successful group of trap stations than for the unsuccessful group (Table 5).

No habitat segregation was evident between males and females based on the 10 variables used in stepwise discriminant analysis, although $A R T A R E A$ approached significance $(0.05<P<0.10)$. Likewise, no signi- 
ficant $(\alpha=0.05)$ differences in habitat use existed among age classes between years, or before and after harvest.

Table 5

Mean $(\bar{x})+$ standard error (SE) for untransformed habitat variables selected to classify successful and unsuccessful trap stations via stepwise discriminant analysis for each year, age class, sex class, and before and after harvest of adjacent field crops at the Rosemount Agricultural Experiment Station, Dakota County, Minnesota, USA.

\begin{tabular}{|c|c|c|c|c|c|c|c|}
\hline \multirow{2}{*}{ Analysis } & \multirow{2}{*}{ Variable $^{1}$} & \multicolumn{3}{|c|}{ Successful } & \multicolumn{3}{|c|}{ Unsuccessful } \\
\hline & & $\overline{\mathrm{x}}$. & SE & $\mathrm{N}$ & $\overline{\mathbf{x}}$ & SE & $\mathrm{N}$ \\
\hline 1979 & WOODVEG & 18.4 & 2.2 & 37 & 7.9 & 1.8 & 38 \\
\hline \multirow{2}{*}{1980} & WOODVEG & 24.2 . & 2.9 & 19 & 9.3 & 1.5 & -56 \\
\hline & ART AREA & 14.3 & 6.2 & & 0.9 & 0.5 & \\
\hline Juveniles & WOODVEG & 20.4 & 2.6 & 30 & 7.9 & 1.5 & 44 \\
\hline Unaged & WOODVEG & 18.7 & 2.5 & 25. & 9.8 & 1.8 & 49 \\
\hline Adults & GRASS $>2$ & 22.6 & 3.4 & 15 & 9.0 & 1.5 & 59 \\
\hline Females & WOODVEG & 18.3 & 2.4 & 30 & 9.4 & 1.9 & 44 \\
\hline \multirow{3}{*}{ Males } & WOODVEG & 21.2 & 2.4 & 32 & 6.7 & 1.4 & 42 \\
\hline & STUMPDIS & 93.6 & 24.9 & & 136.0 & 19.7 & \\
\hline & $A R T A R E A$ & 9.4 & 3.7 & & 0.2 & 0.1 & \\
\hline Pre-harvest & WOODVEG & 20.6 & 3.8 & & 11.0 & 1.6 & 59 \\
\hline Post-harvest & WOODVEG & 18.6 & 2.0 & 38 & 7.4 & 1.9 & 37 \\
\hline
\end{tabular}

1 Variables are arranged in order of entry into the discriminant functions; see Table 1 for an explanation of variable acronyms.:

\section{DISCUSSION}

\section{Habitat Features}

The importance of woody vegetation to cottontails is evident (Table 4). WOODVEG characterizes Picea, young Pinus, and shrubby plant species, such as L. tatarica, Caragana, and Sambucus pubens in shelterbelts and $U$. pumila in waste areas. Trap stations exhibiting large WOODVEG values often were surrounded by an abundance of Rubus canes in addition to the above-mentioned species. Numerous studies have demonstrated the importance of conifers and shrubby vegetation as escape cover (e.g., Linder \& Hendrickson, 1956; Bigham, 1970) and winter food (Sweetman, 1949 ; Fitzsimmons, 1978). Because cottontails rely on the features represented by WOODVEG throughout the year (Chapman, 1947), WOODVEG may justifiably be termed an essential habitat component (Podoll, 1979). In addition, habitat use by males is influenced by STUMPDIS and ARTAREA (Tables $4 \& 5$ ). The avoidance of stumps by males cannot be explained, but Bigham (1970), Trent \& Rongstad (1974), and Smith \& Kirkpatrick (1974) noted the value of artificial 
cover to $S$. floridanus for shelter and predator evasion. Discriminant analysis failed to disclose ARTAREA as a feature influencing habitat use by females, yet Smith \& Kirkpatrick (1974) documented female dominance in use of artificial dens. If females use artificial cover sites extensively, reduced success in capturing females may result for traps proximal to artificial sites due to a decreased reliance on these traps for shelter (Huber, 1962). Juvenile and unaged segments of the population concentrated use in areas characterized by vegetation with high WOODVEG values, but adult habitat use was influenced by GRASS $>2$ (Tables 4 \& 5). Mowing of grassy areas encourages increased plant production and improved visibility for predator detection, thus creating important feeding centers for S. floridanus (Lord, 1963 ; Korschgen, 1980). Moreover, pregnant females prefer to construct nests in grassy areas (Linder \& Hendrickson, 1956). The lack of WOODVEG as a significant determinant of habitat use by adults (Table 4) should not be interpreted as indicating that this habitat feature is biologically unimportant to adults. The majority of frequently-mowed areas at the Station consists of farmstead lawns adjacent to farmstead stelterbelts. These shelterbelts contain conifers and shrubby vegetation contributing to large WOODVEG values at trap stations.

Optimal habitats generally are the only sites used by individuals when population densities are low (Keith \& Windberg, 1978 ; Partridge, 1978). Hence, essential habitat features that indicate plausible environmental factors determining use of optimal habitat by $S$. floridanus may be apparent only when habitat use is compared between periods of high and low density. Therefore, the addition of ARTAREA as an influential habitat feature in 1980 (Table 4), coinciding with a $55 \%$ decline in population levels from the previous year, suggests that artificial cover is of paramount importance to cottontails as potential shelter from predators and inclement weather. Abandoned sheds and junkpiles proximal to or within shelterbelts commonly concealed striped skunk (Mephitis mephitis) dens and woodchuck (Marmota monax) burrows that were used by $S$. floridanus. Captured cottontails frequently ran directly to artificial cover upon release.

\section{Use of Habitat Types}

Shelterbelts exhibited the largest mean values of WOODVEG and ARTAREA (22.5 and 7.7), followed in descending order by waste areas (4.5 and 0.3 ) and fencerows/roadsides ( 0.7 and 0.3 ). This progression suggests that shelterbelts represent the most preferred habitat type, whereas fencerows/roadsides were least important. Moreover, a greater 
proportion of trap stations in shelterbelts and waste areas were used relative to fencerows/roadsides in 1979 (Table 3), and the same pattern was evident (although not statistically significant) in 1980 .

The relative suitability of a habitat type for $S$. floridanus may be inferred in several ways. First, populations in superior habitat types typically do not experience drastic oscillations in density over a multiyear period (Keith \& Windberg, 1978). Consequently, monitoring population fluctuations over time is one method for assessing suitability of a habitat type. The sharp decreases in population densities of waste area and fencerow/roadside habitat types from 1979 to 1980 did not occur in shelterbelts. Population levels in shelterbelts did drop from 11.5 to 9.0 individuals/ha, but this reduced density was still quite high compared to other studies (cf. Fitzsimmons, 1978 ; Chapman et al., 1980). Second, relative use of habitat types by residents may offer insight regarding the differential worth of habitat types. $R I$ values indicated that more cottontails than expected were likely to establish residency in shelterbelts, whereas animals captured in fencerow/roadside habitat were generally transients and/or used the habitat on a temporary basis in conjunction with a contiguous shelterbelt. Residents occupied waste areas in approximately equal proportion to the availability of this habitat type. Third, physical condition of individuals may provide an index to habitat suitability. For instance, Chapman et al. (1977) discovered that harsh environments produced cottontails with lower $C I$ values than individuals in mild environments. In the current study, mean $C I$ values suggested better physical condition of cottontails in shelterbelts than in fencerows/roadsides, and better condition of individuals in fencerows/ roadsides than in waste areas. Poor physical condition in waste areas may be a function of soil infertility and its concomitant negative effect on forage quality in this habitat type (cf. Crawford, 1950).

Juveniles used comparable proportions of trap stations in each of the 3 habitat types (Table 3 ), but the extent of their fencerow/roadside use may be overestimated if individuals were captured while dispersing from natal sites located either in this herbaceous habitat type or in adjacent fields. Adults used a greater proportion of trap stations in shelterbelts compared to fencerows/roadsides, but this is not surprising given the influence of GRASS $>2$ on adult habitat use (Table 4) and the proximity of shelterbelts to mowed lawns. Females were rather indiscriminant in their use of habitat types, but males rarely occurred in fencerows/roadsides relative to shelterbelts and waste areas (Table 3). 


\section{Effect of Crop Harvest on Habitat Use}

Woody vegetation significantly influenced habitat use both before and after harvest (Table 4). Cottontails appeared less dependent on woody vegetation prior to harvest, for they used similar proportions of trap stations in each habitat type (Table 3). Following harvest, however, proportionately more trap stations were used in the 2 habitat types containing woody vegetation, shelterbelts and waste areas, than in fencerows/roadsides (Table 3), and an increase in intensity of use was indicated by significantly higher probabilities of capture in the wooded habitat types. A portion of this increase may be due to increased fall population levels (Schwartz, 1941), but movements of animals into wooded sites from harvested fields increased capture rates substantially. Home range shifts triggered by harvesting activities do occur, and displaced cottontails create population concentrations during autumn and winter by relocating in adjacent wooded habitat (Anderson \& Pelton, 1976).

Reliance by $S$. floridanus on woody vegetation, and to a lesser extent artificial cover, suggests that a non-wooded habitat type with little artificial cover would be unsuitable for permanent occupancy by this species in a modern agro-ecosystem. Fencerow/roadside is such a habitat type. Fencerows/roadsides are unfit for long-term use, as evidenced by an $R I$ value of -1.86 , and probably are useful primarily as feeding sites during the growing season (Bigham, 1970). The value of fencerows/roadsides may be enhanced if located proximal to shelterbelts. For example, movements between shelterbelts and nearby fencerows/roadsides accounted for $13.7 \%$ of all trap-revealed movements in the present study. Wegner \& Merriam (1979) concluded that fencerows adjacent to insular woodlots function as habitat corridors for birds and small mammals, thereby reducing the isolating effect induced by surrounding farmland.

In summary, the present study elucidates the relative superiority of shelterbelts versus waste areas and fencerows/roadsides as suitable habitat for S. floridanus. Further, our findings emphasize the value of shrubby vegetation and artificial cover in maintaining viable populations of this important game species in agricultural areas.

Acknowledgements: Thanks are extended to J. A. Cooper, P. A. Jordan, and H. Scholten for reviewing the manuscript. We gratefully acknowledge the financial support provided by a University of Minnesota Graduate School Fellowship (to R. Swihart), by the Minnesota Agricultural Experiment Station, and by grants (to R. Yahner) from the Graduate School of the University of Minnesota, the National Rifle Association of America, and the Max McGraw Wildlife Foundation. Computer costs were defrayed by the University of Minnesota Computer Center. 


\section{REFERENCES}

1. Allen, D. L., 1949: The farmer and wildlife. Wildl. Manage. Inst: 1-84. Washington, D.C.

2. Anderson B. F. \& Pelton M. R., 1976: Movements, home range, and cover use: factors affecting the susceptibility of cottontails to hunting. Proc. Conf. Southeast. Assoc. Fish and Wildl. Agencies, 30: 525-535.

3. Bailey J. A., 1968: A weight-length relationship for evaluating physical condition of cottontails. J. Wildl. Manage., 32: 835-841.

4. Bailey J. A., 1969: Trap responses of wild cottontails. J. Wildl. Manage., 33: $48-58$.

5. Bigham S. R., 1970: The comparative utility of plant life-form and other characteristics in evaluating the habitat of the cottontail. Ph. D. unpubl. thesis, Oklahoma St. Univ.

6. Chapman F. B., 1947: What brambles mean to wildlife. Ohio Conserv. Bull., 11: $20-21$.

7. Chapman J. A., Harman A. L. \& Samuel D. E., 1977: Reproductive and physiological cycles in the cottontail complex in western Maryland and nearby West Virginia. Wildl. Monogr., 56: 1-73.

8. Chapman J. A., Hockman, J. G. \& Ojeda C. M. M., 1980: Sylvilagus floridanus. Mammal. Sp. No. 136.

9. Chatterjee S. \& Price B., 1977: Regression analysis by example. John Wiley \& Sons: $1-228$. New York.

10. Conover W. J., 1971: Practical nonparametric statistics. John. Wiley \& Sons: $1-462$. New York.

11. Crawford B. T., 1950: Some specific relationships between soils and wildlife. J. Wildl. Manage., 14: 115-123.

12. Dixon W. J. \& Brown M. B., 1979: BMDP-79 Biomedical Computer Programs P-Series. Univ. California Press: 1-880. Berkeley.

13. Dueser R. D. \& Shugart H. H., 1978: Microhabitats in a forest-floor small mammal fauna. Ecology, 59: 89-98.

14. Dueser R. D. \& Shugart H. H., 1979: Niche pattern in a forest-floor small mammal fauna. Ecology, 60: 108-118.

15. Evans K. E. \& Probasco G. E., 1977: Wildlife of the prairies and plains. U. S. Dep. Agric., Forest Serv. Gen. Tech. Rep. NC-29.

16. Fitzsimmons M., 1978: Influence of habitat on a west-central Indiana cottontail population. M.S. unpubl. thesis, Purdue Univ.

17. Friley C. E. Jr., 1955: A study of cottontail habitat preferences on a southern Michigan farming area. Michigan Dep. Conserv. Pittman-Robertson Proj. No. W-48-R.

18. Gottfried B. M., 1979: Small mammal populations in woodlot islands. Amer. Midland Natur., 102: 105-112.

19. Hendrickson G. O., 1947: Cottontail management in Iowa. Trans. N. Amer. Wildl. \& Natur. Resour. Conf., 12: 473-479.

20. Kabat C. \& Thompson D. R., 1963: Wisconsin quail, 1834-1962. Population dynamics and habitat management. Wisconsin Conserv. Dep. Tech. Bull. 30.

21. Keith L. B. \& Windberg L. A., 1978: A demographic analysis of the snowshoe hare cycle. Wildl. Monogr., 58: 1-70.

22. Kline P. D., 1965: Factors influencing roadside counts of cottontails, J. Wildl. Manage., 29: 665-671, 
23. Korschgen L. J., 1980: Food and nutrition of cottontail rabbits in Missouri. Missouri Dep. Conserv. Terrestrial Ser. No. 6.

24. Labisky R. F., 1976: Midwest pheasant abundance declines. Wildl. Soc. Bull., 4: $182-183$.

25. Linder R. L. \& Hendrickson G. O., 1956: Use of rearing cover by Mearns cottontail. Proc. Iowa Acad. Sci., 63: 732-736.

26. Lord R. D. Jr., 1963: The cottontail rabbit in Illinois. Illinois Dep. Conserv. Tech. Bull. No. 3.

27. Overton W. S., 1971: Estimating the numbers of animals in wildlife populations. [In: "Wildlife management techniques", R. H. Giles, ed.]. The Wildlife Society: 403-455. Washigton, D.C.

28. Partridge L., 1978: Habitat selection. [In: "Behavioural ecology", J. R. Krebs, N. B. Davies, eds.]. Sinauer Associates: 351-376. Sunderland, Massachusetts.

29. Podoll E. B., 1979: Utilization of windbreaks by wildlife. [In: "Great Plains Forestry Committee Windbreak Management Workshop”, K. Thompson, E. Varley, eds.]. Great Plains Agric. Council Publi. No. 92.

30. Rao C. R., 1973: Linear statistical inference and its applications. John Wiley \& Sons: $1-625$. New York.

31. Schwartz C. C., 1973: The cottontail and white-tailed jackrabbit in Iowa 1963 to 1972. Iowa Wildl. Res. Bull. No. 6.

32. Schwartz C. W., 1941: Home range of the cottontail in central Missouri. J. Mammal., 22: 386-392.

33. Simberloff D. S., 1974: Equilibrium theory of island biogeography and ecology. Annu. Rev. Ecol. Syst., 5: 161-182.

34. Smith M. \& Scholten H., 1980: Planting trees for farmstead shelter. Univ. Minnesota Agric. Ext. Serv. Bull. 196.

35. Smith R. J. \& Kirkpatrick C. M., 1974: Microclimatic measurements and use of artificial shelter by confined cottontails. Proc. Indiana Acad. Sci., 83: 146-154.

36. Sokal R. R. \& Rohlf F. J., 1969: Biometry. W. H. Freeman \& Co: 1-776. San Francisco.

37. Sweetman H. L., 1949: Further studies of the winter feeding habits of cottontails rabbits. Ecology, 30: $371-376$.

38. Swihart R. K., 1981: Use of farmland habitat patches by the eastern cottontail. M.S. unpubl. thesis, Univ. Minnesota.

39. Trent T. T. \& Rongstad O. J., 1974: Home range and survival of cottontail rabbits in southwestern Wisconsin. J. Wildl. Manage., 38: 459-472.

40. Vance R. D., 1976: Changes in land use and wildlife populations in southeastern Illinois. Wildl. Soc. Bull., 4: 11-15.

41. Wegner J. F. \& Merriam G., 1979: Movements by birds and small mammals between a wood and adjoining farmland habitats. J. Appl. Ecol., 16: 349-357.

42. Wiens J. A., 1976: Population responses to patchy environments. Annu. Rev. Ecol. Syst., 7: 81-120.

43. Yahner R. H., 1980: Breeding bird censuses 111-117. Amer. Birds, 34: 71-73.

44. Zarnoch S. J., 1979: Simulation of effects of learned trap response on three estimates of population size. J. Wildl, Manage., 43: 474-483.

Accepted, February 14, 1982. 
Robert K. SWIHART i Richard H. YAHNER

\section{WYKORZYSTYWANIE PRZEZ SYLVILAGUS FLORIDANUS ROZPROSZONYCH SRODOWISK POLNYCH}

\section{Streszczenie}

W latach 1979-1980, w intensywnie rolniczym okręgu południowej Minnesoty prowadzono badania wpływu biotycznych i abiotycznych czynników wpływających na letnio-jesienne wykorzystanie środowiska przez Sylvilagus floridanus (Tabela 1, Ryc. 1). Badano również różne typy środowisk jak: pasy ochronne, nieużytki, pobocza drúg i pasy ziemi wzdłuż ogrodzeń (Tabela 2, 3). Analiza dyskryminacyjna pozwoliła stwierdzić wykorzystywanie terenu przez $S$. floridanus zależnie od zagęszczenia drzew i okrywy roślinnej (Tabela 4). Osobniki występujące w pasach ochronnych były w lepszej kondycji fizycznej i mniej obniżały swą liczebność niż osobniki zamieszkujące nieużytki czy też pasy gruntów wzdłuż dróg i ogrodzeń. Pasy ochronne stwarzały także najdogodniejsze warunki do stałego zasiedlania ich przez $S$. floridanus. Samice młode i dorosłe w jednakowy sposób wykorzystywały badane środowiska, podczas gdy samce były łowione częściej niż się spodziewano na pasach ochronnych i nieużytkach (Tabela 5, Ryc. 2). Usuwanie plonów zbóż z pól powoduje wzrost zagęszczenia $S$. floridanus w pasach ochronnych i na nieużytkach. 